\title{
Game Edukasi: Apakah membuat belajar lebih menarik?
}

\author{
Loviga Denny Pratama, ${ }^{1,}$ \\ Ahmad Bahauddin ${ }^{2}$ \\ Wahyu Lestari ${ }^{3}$ \\ ${ }^{1,3}$ Tadris Matematika, Institut Ilmu Keislaman Zainul Hasan Genggong \\ ${ }^{2}$ Universitas Negeri Yogyakarta \\ loviga.pratama@gmail.com
}

\begin{abstract}
Era Industri 4.0 has prompted academics to be able to apply a technology in a learning. However, this condition is still not supported by the availability of learning media used in schools. Therefore, this study aims to describe the response of academics, to educational game in learning. Two hundred twenty one students and fifty-three teachers from Probolinggo were randomly allocated to be the subject of this study. The responses collected with non-test techniques, were analyzed quantitatively and qualitatively. The results indicated educational game gain a positive response and greatly needed by academics. Furthermore, this result can be followed up for media developers and researchers to test the educational game in learning.
\end{abstract}

\section{Pendahuluan}

Perkembangan teknologi di era Industri 4.0 sangat mempengaruhi dunia pendidikan. Situasi ini menyebabkan pergeseran paradigma dan praktek pendidikan yang awalnya bersifat menyajikan informasi (ready to use) menjadi membekali peserta didik dengan kemampuan mencari tahu, digital literacy, penyelesaian masalah, dan kreativitas. Oleh karena itu, perkembangan teknologi menjadi sebuah tantangan baru dalam pembelajaran era Industri 4.0. Bahkan dalam Permendikbud telah menyarankan bahwa dalam salah satu prinsip pembelajaran perlu memunculkan pemanfaatan teknologi untuk meningkatkan efektivitas dan efisiensi pembelajaran (Permendikbud, 2016). Mandat ini mendorong akademisi, termasuk guru didalamnya, untuk membuat dan menggunakan sauatu media pembelajaran dari teknologi yang dapat membantu siswa memahami suatu materi pembelajaran.

Meskipun kita dapat menemukan banyak teknologi yang dapat membantu dan memfasilitasi siswa dalam memahami konsep pembelajaran (Huang, Hew, \& Lo, 2018), namun sangat jarang ditemui penggunaan media berbasis game edukasi di dalam kelas. Padahal penelitian sebelumnya yang berfokus pada pendekatan pembelajaran menyenangkan yang difasilitasi oleh suatu game, dapat memberikan dampak positif dalam sebuah pembelajaran (Lago, 2017; Pratama \& Setyaningrum, 2018). Terlebih lagi, anak yang berusia 
sekitar 11-14 tahun sudah mulai menghabiskan waktu dengan bermain game in perangkat mobile (Rideout, Foehr, \& Roberts, 2010).

Sebuah aplikasi game dapat kita manfaatkan melalui media teknologi seperti smartphone, komputer/laptop, dan tablet. Dimana pengguna ketiga teknologi tersebut di negara Indonesia berdasarkan survey Stat Counter 2018, situs analisi statistik, menunjukkan bahwa sebanyak $74,42 \%$ pengguna smartphone, $24,22 \%$ pengguna komputer/laptop, dan $1,36 \%$ pengguna tablet (Stat Counter, 2018). Berdasarkan survey tersebut terlihat bahwa sebagian besar warga Indonesia telah memiliki smartphone. Lebih lanjut, berdasarkan data yang dikeluarkan oleh Kementerian Komunikasi dan Informatika Republik Indonesia pada tahun 2016 menunjukkan bahwa sebanyak 66,4\% siswa SD, 69,7\% siswa SMP, dan 79,1\% siswa SMA telah memiliki smartphone (Kementerian Komunikasi dan Informatika Republik Indonesia, 2016). Berdasarkan data tersebut, media pembelajaran berbasis smartphone sangat mungkin dilakukan untuk siswa sekalah dasar sampai menengah.

Media pembelajaran berbasis smartphone ini tentunya mempunyai kelebihan yakni kemudahan dalam mengakses dimana saja dan kapan saja (Mohammad, Fayyoumi, \& AlShathry, 2015). Sehingga hal ini menjadikan kemudahan jika digunakan sebagai alat untuk membantu siswa belajar. Mengingat media pembelajaran yang ada sekarang ini banyak menampilkan video sehingga memerlukan alat bantu berupa laptop, PC, dan proyektor yang kurang mudah untuk kita gunakan dimana saja dan kapan saja. Namun, keunggulan ini kurang dimanfaatkan dalam kegiatan pembelajaran di kelas maupun di luar kelas. Siswa cenderung mempergunakan smartphone hanya sebagai sarana hiburan dan bersosial media (Woodcock, Middleton, \& Nortcliffe, 2012). Hal ini dikarenakan kurangnya media pembelajaran berbantuan smartphone dalam menyampaikan informasi suatu materi pembelajaran yang menarik minat siswa.

Media pembelajaran berbasis smartphone sudah banyak kita temukan, namun sebagian besar hanya bersifat satu arah. Pengguna hanya bisa mengakses ringkasan materi yang dipelajari serta mengikuti alur yang telah diprogramkan oleh pembuat. Sehingga disini diperlukan suatu media pembelajaran yang interaktif sekaligus menarik minat siswa dalam mempelajari materi, yakni salah satunya melalui media game edukasi.

Meskipun beberapa tahun lalu ada kontroversi di kalangan akademisi mengenai penggunaan game edukasi sebagai alat pembelajaran di sekolah. Di satu sisi, beberapa akademisi tidak setuju karena akan mengganggu proses pembelajaran di kelas, sementara di sisi lain, beberapa akademisi melihat banyak potensi yang perlu digunakan dalam pembelajaran berbasis game edukasi (Sulisworo, 2013). Namun, para pendidik dan desainer 
pembelajaran saat ini menyadari bahwa game edukasi telah menyediakan peluang baru untuk ketersediaan bentuk pembelajaran baru dan berbeda, termasuk hubungan antara peserta didik, guru, dan objek pembelajaran (Kadry \& Roufayel, 2017; Setyaningrum, Pratama, \& Ali, 2018). Mengingat pendekatan-pendekatan pembelajaran menyenangkan memberikan dampak positif dalam sebuah pembelajaran (Prahmana, Zulkardi, \& hartono, 2012; Pratama, Hobri, \& Lestari, 2016; Pratama \& Setyaningrum, 2018), tampaknya masuk akal untuk game edukasi digunakan sebagai fasilitas belajar.

Oleh karena itu, studi ini mendeskripsikan tanggapan akademisi (guru dan siswa) dalam kaitannya dengan media game edukasi kususnya di daerah Probolinggo. Dimana di daerah ini mulai memperhatikan perkembangan teknologi pada dunia pendidikan. Para siswa di daerah ini juga sudah diperbolehkan membawa smartphone di sekolah. Adapun hasil dari studi ini dapat dijadikan rujukan dan motivasi para praktisi pendidikan untuk membuat suatu media pembelajaran berbasis game edukasi.

\section{Metode}

Pendekatan penelitian yang digunakan dalam studi ini adalah pendekatan kuantitatif dan kualitatif. Adapun fokus pada studi ini yakni pada mendeskripsikan tanggapan akademisi, baik guru maupun siswa, terhadap media game edukasi dalam pembelajaran.

Subjek pada penelitian ini mengikutsertakan akademisi di Probolinggo yang dipilih melalui teknik convenience sampling. Sehingga diperoleh subjek sebanyak 221 siswa (102 laki-laki dan 119 perempuan) dan 53 guru. Selanjutnya 274 subjek ini akan dikumpulkan tanggapan persepsi terhadap media game edukasi. Tanggapan dikumpulkan melalui teknik non-tes melalui angket.

Angket digunakan untuk mengumpulkan pendapat akademisi tentang media game edukasi. Terdapat 3 aspek yang menjadi fokus pada pengumpulan data melalui angket ini, yakni kepemilikan smartphone, respon terhadap media game edukasi, dan penggunaan game edukasi. Adapun masing-masing butir pernyataan/pertanyaan dapat dilihat pada Tabel 1.

Tabel 1. Aspek dan Butir pada Angket

\begin{tabular}{|l|ll|}
\hline \multicolumn{1}{|c|}{ Aspek } & \multicolumn{1}{c|}{ Butir Pernyataan/Pertanyaan } \\
\hline Kepemilikan smartphone & $\begin{array}{ll}\text { 1. } & \text { Apakah Anda memiliki smartphone Android/iOS? } \\
\text { (pilihan jawaban: iya / tidak) }\end{array}$ \\
\hline $\begin{array}{l}\text { respon terhadap media game } \\
\text { edukasi }\end{array}$ & $\begin{array}{l}\text { 2. } \\
\text { mendukung pengembangan game Edukasi untuk } \\
\text { pembelajaran di sekolah }\end{array}$ \\
& $\begin{array}{ll}\text { 3. } \\
\text { 4ame edukasi dapat meningkatkan kognitif siswa } \\
\text { game edukasi dapat meningkatkan afektif siswa } \\
\text { 5. }\end{array}$ \\
\hline
\end{tabular}




\begin{tabular}{|l|l|}
\hline & $\begin{array}{ll}\text { 6. } & \text { game edukasi dapat mengefisienkan waktu pembelajaran } \\
\text { 7. } & \text { game edukasi dapat meningkatkan minat belajar siswa } \\
\text { 8. } & \text { persaingan skor (sistem ranking) diperlukan di dalam } \\
\text { game edukasi } & \text { skor di dalam game edukasi dapat dijadikan nilai untuk } \\
\text { rapor }\end{array}$ \\
\hline penggunaan game edukasi & $\begin{array}{l}\text { 10. Bagaimana pendapat anda tentang penggunaan game } \\
\text { edukasi di sekolah? }\end{array}$ \\
$\begin{array}{l}\text { 11. Jika Anda setuju pada butir 3, 4 dan 5, apa yang menjadi } \\
\text { alasan anda akan hal tersebut? }\end{array}$ \\
\hline
\end{tabular}

Tabel 2. Pedoman Penskoran Angket

\begin{tabular}{|c|c|}
\hline Respon & Skor \\
\hline Sangat Setuju & 5 \\
\hline Setuju & 4 \\
\hline Ragu-ragu & 3 \\
\hline Tidak Setuju & 2 \\
\hline Sangat Tidak Setuju & 1 \\
\hline
\end{tabular}

Terdapat 8 pernyataan pada aspek respon terhadap media game edukasi. Dalam hal ini penentuan skor pada pernyataan dibuat dalam lima skala penilaian (lihat Tabel 2). Masing-masing butir pernyataan aspek tersebut dianalisis untuk mengetahui respon siswa terhadap media pembelajaran yang dikembangkan. Adapun perhitungannya dilakukan langkah berikut:

(a) Mengkategorikan setiap butir pernyataan pada angket berdasarkan alternatif pilihan jawaban

(b) Menghitung persentase respon siswa pada angket di tiap kategori berdasarkan rumus berikutL

$$
P_{i j}=\frac{\text { Jumlah respon aspek } k e-i \text { kategori } k e-j}{\text { Jumlah maksimal respon aspek ke }-i \text { kategori } k e-j} \times 100 \%
$$

Keterangan:

$P_{i j} \quad:$ persentase respon aspek ke-i kategori ke-j

(c) Menghitung persentase respon total tiap kategori melalui rumus:

$$
P_{j}=\sum_{i=1}^{n} P i j
$$

Keterangan:

$\mathrm{Pj} \quad$ : persentase respon total tiap kategori

n : banyaknya aspek

(d) Menghitung rerata persentase total melalui rumus: 


$$
R T=\frac{\sum_{i=1}^{n} P j}{m}
$$

Keterangan:

RT : rerata persentase total

(e) Menentukan kategori respon positif berdasarkan persentase yang diperoleh. Adapun kategori respon menurut Khabibah (Yamasari, 2010) dapat dilihat pada Tabel 3 berikut.

Tabel 3. Kategori Respon Siswa

\begin{tabular}{|l|c|l|}
\hline No. & Interval Rerata Persentase Total (RT) & \multicolumn{1}{|c|}{ Kriteria } \\
\hline 1. & $R T \geq 85 \%$ & Sangat Positif \\
\hline 2. & $70 \% \leq R T<85 \%$ & Positif \\
\hline 3. & $50 \% \leq R T<70 \%$ & Kurang Positif \\
\hline 4. & $R T<50 \%$ & Tidak Positif \\
\hline
\end{tabular}

Sedangkan pada aspek penggunaan game edukasi dimaksudkan untuk menggali lebih mendalam terhadap jawaban responden pada angket. Melalui butir pernyataan tersebut peneliti akan mengetahui hal-hal yang lebih mendalam tentang subjek penelitian dalam menginterpretasikan persepsinya terhadap media edukasi.

\section{Hasil dan Pembahasan}

Berdasarkan hasil angket pada aspek kepemilikan smartphone, semua subjek penelitian diketahui telah memiliki perangkat smartphone. Memang bagi sebagian kalangan, perangkat smartphone telah menjadi kebutuhan pokok untuk membantu profesi mereka (Chuzaimah, Mabruroh, \& Fereshti, 2011). Begitu juga sebagai akademisi, smartphone mulai dipandang perlu karena dapat memfasilitasi mereka dalam mempelajari materi tertentu (Setyaningrum et al., 2018).

Adapun data respon siswa terhadap media dapat dilihat pada Tabel 4. Hasil ini menunjukkan bahwa responden menyatakan setuju jika game edukasi diterapkan dalam pembelajaran. Tanpa dipungkiri mendesain suasana belajar berbasis game dapat menciptakan iklim pembelajaran yang menyenangkan tanpa mengesampingkan materi yang harus dipelajari siswa (Barzilai \& Blau, 2014). Hal ini terlihat dalam penelitian ini, dimana respon responden sangat positif dalam menerapkan game edukasi.

Tabel 4. Hasil Rerata Skor Angket

\begin{tabular}{|l|c|c|}
\hline \multicolumn{1}{|c|}{ Butir Respon } & $\begin{array}{c}\text { Rentan } \\
\text { skor }\end{array}$ & $\begin{array}{c}\text { Rerata } \\
\text { skor }\end{array}$ \\
\hline $\begin{array}{l}\text { mendukung pengembangan game edukasi untuk pembelajaran } \\
\text { di sekolah }\end{array}$ & $1-5$ & 4.7 \\
\hline game edukasi dapat meningkatkan kognitif siswa & $1-5$ & 4.8 \\
\hline game edukasi dapat meningkatkan afektif siswa & $1-5$ & 4.8 \\
\hline game edukasi dapat meningkatkan psikomotor siswa & $1-5$ & 4.5 \\
\hline
\end{tabular}




\begin{tabular}{|l|c|c|}
\hline \multicolumn{1}{|c|}{ Butir Respon } & $\begin{array}{c}\text { Rentan } \\
\text { skor }\end{array}$ & $\begin{array}{c}\text { Rerata } \\
\text { skor }\end{array}$ \\
\hline game edukasi dapat mengefisienkan waktu pembelajaran & $1-5$ & 4.3 \\
\hline game edukasi dapat meningkatkan minat belajar siswa & $1-5$ & 4.9 \\
\hline $\begin{array}{l}\text { persaingan skor (sistem ranking) diperlukan di dalam game } \\
\text { edukasi }\end{array}$ & $1-5$ & 4.1 \\
\hline skor di dalam game edukasi dapat dijadikan nilai untuk rapor & $1-5$ & 4.0 \\
\hline \multicolumn{2}{|c|}{ Rerata Skor } & 4.5 \\
\hline \multicolumn{2}{|c|}{ Persentase Response } & $90 \%$ \\
\hline
\end{tabular}

Jika ditinjau lebih lanjut, pada aspek penggunaan game edukasi dikemukakan pendapat mereka mengenai kegunaan game pada saat pembelajaran. Sebanyak 91,02\% responden menunjukkan pendapat yang positif dalam pengadaan game edukasi dalam sebuah pengajaran. Adapun tanggapan secara keseluruhan, mereka beranggapan melalui media game yang terfasilitasi melalui teknologi tentunya membuat materi yang ditampilkan lebih menarik serta disertai ilustrasi-ilustrasi yang jelas sehingga lebih mudah membayangkan dan memahami materi. Memang telah diteliti sebelumnya, berkaitan dengan integrasi muatan hiburan pada game dapat menciptakan iklim pembelajaran yang menyenangkan tanpa mengesampingkan materi yang harus dipelajari siswa (Pratama \& Setyaningrum, 2018).

Melalui arguments responden ini menandakan bahwa media teknologi sangat memfasilitasi mereka untuk belajar. Hasil ini didukung dengan temuan sebelumnya (Pratama \& Setyaningrum, 2018), yang mana media teknologi mempunyai sejumlah keunggulan untuk lingkungan belajar. Sehingga melalui media ini membantu menjawab tantangan pembelajaran era Industri 4.0. Terlebih lagi di Probolinggo, melalui penyebaran angket, telah banyak mempunyai media teknologi yakni smartphone. Sehingga bukan tidak mungkin daerah Probolinggo dapat membiasakan pembelajaran di era Industri 4.0.

Namun demikian, $8,98 \%$ responden menyatakan pendapat yang kurang tertarik tentang adanya game edukasi dalam pembelajaran. Mereka beralasan bahwa belum terbiasa belajar dalam kondisi baru yakni belajar dengan menggunakan smartphone. Mereka hanya terbiasa melakoni proses pembelajaran yang formal melalui buku teks. Kondisi yang baru dalam suatu pembelajaran memerlukan beberapa waktu untuk siswa beradaptasi ( $\mathrm{Su}$, Tseng, Lin, \& Chen, 2011). Jadi untuk mengondisikan seperti ini, perlu membiasakan belajar dengan fasilitas smartphone atau perangkat teknologi lainnya. Terlebih lagi di Indonesia (melalui Permendikbud, 2016) mapun di negara lain (melalui NCTM, 2015) mulai menekankan pemanfatan teknologi dalam suatu pembelajaran di kelas. 


\section{Kesimpulan dan Saran}

Secara keseluruhan dari penelitian ini menunjukkan bahwa media game edukasi di lingkungan sekolah Probolinggo sangat dibutuhkan. Mengingat media teknologi, misalnya smartphone, sudah banyak yang memiliki di daerah ini maka bukan tidak mungkin pembelajaran berbasis media game edukasi dapat terealisasikan dengan baik. Respon akademisi juga positif dalam penggunaan media ini. Sehingga berdasarkan kebutuhan dan respon positif dari akademisi Probolinggo, dapat dikatakan bahwa game edukasi dapat memungkinkan belajar lebih menarik.

Temuan penelitian ini memberikan beberapa peluang dalam meneliti lebih lanjut berkaitan game edukasi. Melalui hasil penelitian ini diharapkan beberapa peneliti untuk mengujicobakan media game edukasi di daerah Probolinggo maupun daerah lainnya. Respon positif akademisi ini juga memberi peluang bagi para peneliti untuk meneliti dampak game edukasi terhadap aspek kognitif dan afektif siswa.

\section{Daftar Pustaka}

Barzilai, S., \& Blau, I. (2014). Scaffolding game-based learning: Impact on learning achievements, perceived learning, and game experiences. Computers \& Education, 70(JANUARY 2014), 65-79. https://doi.org/10.1016/j.compedu.2013.08.003

Chuzaimah, C., Mabruroh, M., \& Fereshti, N. D. (2011). Smartphone: Antara Kebutuhan Dan E-Lifestyle. Telematika, 38.

Huang, B., Hew, K. F., \& Lo, C. K. (2018). Investigating the effects of gamificationenhanced flipped learning on undergraduate students' behavioral and cognitive engagement. Interactive Learning Environments, $0(0), \quad 1-21$. https://doi.org/10.1080/10494820.2018.1495653

Kadry, S., \& Roufayel, R. (2017). How to use effectively smartphone in the classroom. In IEEE Global Engineering Education Conference, EDUCON (pp. 441-447). https://doi.org/10.1109/EDUCON.2017.7942884

Kementerian Komunikasi dan Informatika Republik Indonesia. (2016). Infografis Indikator TIK 2016 Rumah Tangga dan Individu, 7. Retrieved from http://www.kominfo.go.id

Lago, B. L. (2017). Al-Kimia: How to Create a Video Game to Help High School Students Enjoy Chemistry. In M. Ma \& A. Oikonomou (Eds.), Serious Games and Edutainment Applications: Volume II (pp. 259-272). Cham: Springer International Publishing. https://doi.org/10.1007/978-3-319-51645-5_11

Mohammad, H., Fayyoumi, A., \& Al-Shathry, O. (2015). Do we have to prohibit the use of 
mobile phones in classrooms? International Journal of Interactive Mobile Technologies, 9(2), 54-57. https://doi.org/10.3991/ijim.v9i2.4394

NCTM. (2015). Strategic Use of Technology in Teaching and Learning Mathematics A Position of the National Council of Teachers of Mathematics. Retrieved November 1, 2017, from http://www.nctm.org/Standards-and-Positions/Position-Statements/StrategicUse-of-Technology-in-Teaching-and-Learning-Mathematics/

Permendikbud. (2016). Peraturan Mentri Pendidikan dan Kebudayaan Nomor 22 Tahun 2016 Tentang Standar Proses Pendidikan Dasar dan Menengah.

Prahmana, R. C. I., Zulkardi, Z., \& hartono, Y. (2012). Learning Multiplication Using Indonesian Traditional game in Third Grade. Journal on Mathematics Education, 3(2), 115-132. Retrieved from http://ejournal.unsri.ac.id/index.php/jme/article/view/570

Pratama, L. D., Hobri, \& Lestari, N. D. S. (2016). Pengembangan Perangkat Pembelajaran Matematika Berbasis Pendekatan Joyfull Learning pada Sub Pokok Bahasan Segitiga untuk Meningkatkan Motivasi dan Hasil Belajar Siswa Kelas VII SMP. Universitas Jember.

Pratama, L. D., \& Setyaningrum, W. (2018). Game-Based Learning: The effects on student cognitive and affective aspects. Journal of Physics: Conference Series, 1097(1), 12123. https://doi.org/10.1088/1742-6596/1097/1/012123

Pratama, L. D., \& Setyaningrum, W. (2018). GBL in Math Problem Solving: Is it Effective? International Journal of Interactive Mobile Technologies (iJIM), 12(6), 101-111.

Rideout, J. V., Foehr, G. U., \& Roberts, D. F. (2010). Generation m2 : Media in the lives of 8 to 18-year-olds. London: Kaiser Family.

Setyaningrum, W., Pratama, L. D., \& Ali, M. B. (2018). Game-Based Learning in Problem Solving Method: The Effects on Students' Achievement. International Journal on Emerging Mathematics Education, 2(2), 157-164. https://doi.org/http://dx.doi.org/10.12928/ijeme.v2i2.10564

Stat Counter. (2018). Desktop vs Mobile vs Tablet Market Share in Indonesia. Retrieved November 20, 2018, from http://gs.statcounter.com/platform-market-share/desktopmobile-tablet/indonesia

Su, J.-M., Tseng, S.-S., Lin, H.-Y., \& Chen, C.-H. (2011). A personalized learning content adaptation mechanism to meet diverse user needs in mobile learning environments. User Modeling and User-Adapted Interaction, 21(1-2), 5-49. https://doi.org/10.1007/s11257010-9094-0

Sulisworo, D. (2013). The Paradox on IT Literacy and Science's Learning Achievement in 
Secondary School Article Info ABSTRACT Corresponding Author. International Journal of Evaluation and Research in Education (IJERE), 2, 2252-8822.

Woodcock, B., Middleton, A., \& Nortcliffe, A. (2012). Considering the Smartphone Learner: developing innovation to investigate the opportunities for students and their interest. Student Engagement and Experience Journal, 1(1), 1-15. https://doi.org/10.7190/seej.v1i1.38

Yamasari, Y. (2010). Pengembangan media pembelajaran matematika berbasis ICT yang berkualitas. Seminar Nasional Pascasarjana, (979), 1-8. https://doi.org/10.1371/journal.pone.0038182 